\title{
Theories and Practice of CBI in English Teaching Under the Perspective: Language, Content, Speculation
}

\author{
Zhongliang Niu \\ Academic Affairs Office \\ Qilu Normal University \\ Jinan, China
}

\begin{abstract}
CBI (Content-based Instruction Teaching Mode) is the teaching mode which combines language teaching and content teaching together. CBI concept focuses on subject content and students' speculative thinking rather than language points and CBI brings great changes to the traditional language teaching model. CBI, as a teaching mode, combines language content and speculative thinking as a whole, which calls for higher requirements for English teachers.
\end{abstract}

Keywords-CBI language; content; speculation

\section{INTRODUCTION}

Middle School English Teaching Methods issued by Education Department clearly claims that the purpose of English teaching is to improve the students' comprehensive ability especially listening and self-access learning ability. Middle school take advantages of multi-media and network and use new teaching model taking place of the professorcentered teaching model, which is the content-based instruction $(\mathrm{CBI})$. And this requirement provides the proper environment and conditions for English teaching.

\section{CBI TEACHING MODE}

Content-based Instruction refers to an approach to second language teaching in which teaching is organized around the content or information that students will acquire, rather than around a linguistic or other type of syllabus. (Brinton et al, 1989)

CBI implies the total integration of content learning and language learning. In CBI, language learning is combined with content learning, and they are integrated into on concurrent learning process. And the second language is considered as a tool of communication. Content is the vehicle of second language learning.

Content-based instruction is an integrative approach which focuses on language skills and content mastery but it hasn't a certain definition. A diversity of definitions of CBI has been proposed by researchers and educators from different aspects. The applications of CBI in the classroom are also not in the same form because of different communities, schools and personnel. Schools adopt this approach to systematically reinforce students ${ }^{\text {ee }}$ understanding of the content and improve their proficiency in English. In this part, there are several descriptions of CBI from different perspectives. From a functional linguistics view: Mohan (1986) points that language and content should be learned at the same time and his knowledge.

\section{A. Four Characteristics of CBI Model}

The specific knowledge is the core of learning; using true language materials; learning new information; meeting the need of different students' requirements. (Leaver \&Stryker, 1989)

\section{B. The Application Norms of CBI Teaching Model}

Students are the main body of CBI teaching method; CBI teaching Methods emphasizes content as the teaching carrier; CBI teaching method is the integration of all skills.

According to the various course teaching objectives, different models of CBI are applied in the class. So it is the same as the definition of CBI, there are several models of CBI. Sheltered, adjunct, and theme-based model are the three main models which are defined by Brinton et al. (1989). Sheltered and adjunct model are usually used for ESL students language learning. Teachers can help ESL students achieve the same proficiency of language with English as first language students by applying sheltered and adjunct model. Theme-based model is for EFL students, which is the connection subject area and language learning. It also gives teachers more chances to decide what to teach and how to teach, which can arise students learning enthusiasms and leads to a coherent curriculum.

\section{The Differences of CBI Teaching Methods from Traditional Teaching Methods}

Comparing with the traditional teaching methods CBI is the "meaning" teaching method. Specifically speaking, CBI discards the meaningless linguistic exercises and calls for learning both specific knowledge and languages. CBI teaching methods significantly transfer form focus-on- form instruction to focus-on-meaning and function teaching, from 
skill teaching to content teaching, from single subject to multi-subject teaching. (Liu, 2011)

\section{CBI: THE INTEGRATION OF CONTENT AND LANGUAGES}

\section{A. The Relations of Languages and Content}

Languages being the carrier of content, while learning languages students are solving some social problems, culture, politics, mass communication, ethics, which are quite different from traditional learning. Considering the relations of content and languages, students are learning from the visible language studying to invisible language studying. At the very beginning, language learning is more visible. Learning emphasizes on vocabulary, grammar, syntax, rhetoric, passage framework and so on. Gradually and gradually, the attendance to language is more and more on inner content. And in the senior classes, English is the tool of learning major subjects. Visible knowledge learning turns to be invisible linguistics learning.

As far as teaching method is concerned, teaching model is changed from linguistic- based to content-based. Students could not only improve their linguistic ability but also some problem concerning sociology, culturology, politics, mass communication, ethics and so on.

\section{B. Five Principles of $C B I$}

$\mathrm{CBI}$ is the combination of content and languages. The five principles of CBI are as follows: linguistics learning combines with linguistic applications; drawing subject content into class learning in order to arouse students' linguistic studying motivation and learning efficiency; effective linguistic teaching is the combination of linguistic ability and learning experience knowledge and learning environment; linguistic learning should not be confined to the syntax but the specific applications; in the comprehension of major study, students' linguistic ability and cognitive ability are improved at the same time.

\section{CBI AND Students' SPECUlation AbILITY}

CBI would bring up students' speculation ability and students may become smarter with better speculation ability and creativity. This problem would be the ultimate concern of English education reform and the whole country's senior education. Independent thinking is based on rational reasoning basing on truth debate, which is the good anti logos thinking.

In CBI class, the target language is used to introduce the new content and to conduct the relative activities. Thus, the contextualized language learning and language supporting content related communication are facilitated by CBI. However, communication stress and cognitive load always come into being in this process, so teachers are required to help students. The most important two principles for teacher's role in establishing students ${ }^{\text {ee }}$ previous experience and scaffolding the linguistic content are "guiding rather than giving" and "exemplification rather than simplification".
The teaching materials guide the learning and teaching. They can help the learning and teaching process as well. The learning components and methods are determined by the teaching materials for most of the time, which means that the contents, methods and procedures of learning are controlled by them. For theme-based CBI model, the teaching materials should be authentic, interesting, up-todate, and comprehensible. They have the following advantages: 1) emphasis the linguistic knowledge and communicative competence; 2) emphasis the authentic using of the language; 3) emphasis the re-arranging and creating. When selecting texts, teachers should take all these into account. Because there is no textbook for theme-based CBI, teachers should base on the traditional textbooks and 26 look beyond them.

\section{CBI AND ITS DEVELOPING PROSPECTS}

Until now somebody holds prejudice on CBI that CBI should focus on linguistic teaching. It is wrong to ask the teachers to teach other special subjects. As a matter of fact, the core of CBI is linguistic teaching and the key is to change the teaching methods according to the specific groups of students. According to different trades and different majors teachers are supposed to teach languages and general-language education. The purpose of college English teaching is focusing on humanistic quality, crossculture communication and linguistic practice according to our national college talents training. Thus, subject contents contain a lot including natural science, social science, culture, history and so no. College English teachers should have major development plan according to research and teaching. The purpose of talents training is students majoring study and teachers' majoring interest. They may realize their major development purpose by self-effort and cooperation.

\section{A. The Probability of CBI Teaching Method in Linguistic Teaching}

CBI teaching method is the combination of linguistic study and content learning, which would satisfy both culture learning and comprehensive language ability improving. Especially after finishing basic language learning, CBI could inspire students' learning interest and initiatives. Students may become self-conscious learners and probe into knowledge of special subject. Their cognitive ability and thinking ability are improved, which is good for their language study. In a word, CBI is the possible proposal of college English reform.

\section{B. The Enlightenment of CBI on Middle school English Teaching}

Content motivated teaching method focuses on the languages carrying content, which helps learners construct content of special subject, demand and requirement, the balance of language and subject, teachers' training and so on. 


\section{CONCLUSION}

Until now somebody holds prejudice on CBI that CBI should focus on linguistic teaching. It is wrong to ask the teachers to teach other special subjects. As a matter of fact, the core of CBI is linguistic teaching and the key is to change the teaching methods according to the specific groups of students. According to different trades and different majors teachers are supposed to teach languages and general-language education. The purpose of college English teaching is focusing on humanistic quality, crossculture communication and linguistic practice according to our national talents training. Thus, subject contents contain a lot including natural science, social science, culture, history and so no. College English teachers should have major development plan according to research and teaching. The purpose of talents training is students majoring study and teachers' majoring interest. They may realize their major development purpose by self-effort and cooperation.

CBI teaching method is the combination of linguistic study and content learning, which would satisfy both culture learning and improving comprehensive language ability. Especially after finishing basic language learning, CBI could inspire students' learning interest and initiatives. Students may become self-conscious learners and probe into knowledge of special subject. Their cognitive ability and thinking ability are improved which is good for their language study. In a word, CBI is the possible proposal of middla school English reform.

All in all, with the globalization nowadays, the social development needs compound practical and international talents. Thus there are corresponding requirement for talents training and purpose. CBI teaching method comes into the education vision at this background. While CBI meets some problems in China, that is, the target language is not the official language. The background is that text books is outdated the social development, the students' second language is not good. Therefore, it is a demanding job to improve Chinese education reform at the background of educational environment.

\section{REFERENCES}

[1] Brinton, D. M., Snow, M.A.\& Wesche M.(1989). Content-based second language Instruction. New York: Newbury House Publisher.

[2] Leave, B.\&S.Stryker. Content-based instruction for foreign language classrooms [J]. Foreign Language Annals, 1989, (22)3:269-275.

[3] Liu Runqing.Contend -Drived Languge teaching [R] 2011, China Education Linguistic Second Annual Meeting Paper Collection, Xi An, Shan Xi, 2011.5 